\title{
Empower the Women, Develop the Nation! - Validating the Women Empowerment Scale
}

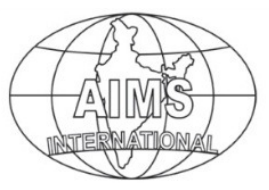

DOI: $10.26573 / 2018.12 .3 .3$

Volume 12, Number 3

September 2018, pp. 171-181

\author{
Beulah Suresh \\ Arivuselvee. V. J. \\ Auxilium College (Autonomous) \\ (beul_bharath@rediffmail.com) \\ (arivuselvee.jayaraman@gmail.com)
}

The paper exemplifies the pilot study of the research work proceeding with the intention of developing and validating the measures of women empowerment. Women empowerment is measured with special reference to the Women, members of Self Help Groups (SHGs). Women empowerment is divided into three dimension, namely, personal empowerment, social empowerment and economic empowerment. These dimensions comprises constructs namely self development, decision making, freedom from domination of family, improvement in social status, freedom of mobility, political and legal awareness and ability to make small and large purchases. The pilot study proceeded with the data collection from 95 SHGs women. The model developed was validated by adopting convergent validity, discriminant validity, construct validity tests. The data was also checked for its reliability using Cronbach's Alpha reliability test. Finally the completion of this pilot study furnishes and indicates that the scheme of this research is of exploratory research. Ultimately, it overlays the measures for the formulation of the strategies that facilitates the empowerment of women and indeed paves path for the strong foundation of the development of the society, in turn the State and Nation.

Keywords: Women, Decision Making, Self Help Groups, Empowerment, Society

\section{Introduction}

Women empowerment is a phenomenon where women incline to be self-governing in all aspects from mind, thought, rights, decision, etc by leaving all social and family limitations. This phenomenon is noticed among the women in the remote areas of all over India with the entry of Self Help Groups (SHGs) which originated in 1975 in Bangladesh. Later during 1986 - 87, SHGs evolved in India. The introduction of SHGs in India is the great sensational gift for the women to augment their skills and to portray all their potentials and proficiencies at the right place with optimum utilization with a yield of constructive output to individuals themselves as well as to the society, in turn, state and nation certainly.

Self Help Groups refers to "Self governed, peer controlled, informal group of people with same socio economic background and having a desire to collective perform common purposes". It is also a holistic programme of micro enterprises 
covering all aspects of self employment, organization of the rural poor into Self Help Groups and their capacity building, planning of activity clusters, infrastructure, credit and marketing.

\section{Bikash Kumar Bora (2017)}

\section{Review of Literature}

His one of the findings states that the membership of Self Help Groups contributes towards augmenting women's competencies not only in private sphere but also in public domain. He recommends that government department in the company of close supervision of government agency, NGOs and civil society organizations ought to assist in forming group and ensure that the groups are formed only with the women who are Below Poverty Line.

\section{Sinu M (2017)}

The aim of the paper is to identify the various activities of self help group and to analyze the financial help and government support to their work and also to analyze the role of self help group in women empowerment. In India, Micro finance and Self Help Group (SHG) intrusions have brought tremendous change in the life of women at the base level.

\section{Madanant Naik and Anthony Rodrigues (2017)}

In their study economic empowerment index and social empowerment index of SHGs women were calculated. The economic empowerment index is the rating score of economic parameters measured in terms of household assets, household income, household expenditure, household savings, loan and housing type of the SHG members. The social parameters are the self confidence in facing financial crisis, meeting official people, enhancement of communication skills, business skills, financial skills and social awareness and recognition about the issues like violence, drugs, alcoholism and government schemes and access to medical facilities, hygienic sanitation facilities and drinking water supply.

\section{Kappa Kondal (2014)}

The author intends to find the impact of Self Help Groups on women empowerment in Gajewal Mandal of Medak District in Andhra Pradesh. The data was collected from 100 women, 25 samples from each village covering four villages using pre designed questionnaire. The major result of the study depicts that there is an increase in their monthly income after joining SHGs. Added to that, 59\% of the respondents agree that their communication skill has been enhanced after entering SHGs. 52\% of the respondents are involved in decision making in agricultural activities and $57 \%$ of the respondents take part in decision making in their own families.

\section{Soumitro Chakravarty and Anant Kumar (2013)}

This paper aims to understand the concept of women empowerment on a holistic basis and critically examine the efforts initiated towards empowering women with special emphasis upon the Self Help Groups(SHGs) based on empirical work progressed in the Ranchi district of Jharkhand state in India. In addition it also aims towards understanding the linkages between SHGs \& women empowerment and proposing suggestions to pace up the empowerment drive paying due attention to the 
local level area specific factors for a developing country like India which has a crucial impact upon region specific women empowerment process.

\section{S. Thangamani and S. Muthuselvi (2013)}

This study concentrates on women empowerment through self help groups in Mettupalayam district of Tamilnadu. The information required for the study has been collected from both the primary and secondary sources. Random sampling method has been followed. Chi- Square test used to find whether the two attributes are associated or not, i.e. socio economic factors and income generating activities.

\section{Y. B. Shambharkar et al., (2012)}

They state that women are the best change agent to knock the core of poverty and are very significant segment in growth at local to global level. The status of women is considered to be the gauge of democratism of any state, an indicator of how human rights are treated. They classified empowerment into five dimensions carrying various parameters. The five dimensions are psychological, cultural, social, economic and political empowerment. The overall impact of self help group on empowerment of women member was calculated by summing the value of all five dimensions. The percentage of respondents appearing in low category of women empowerment was found to be meager (00.71per cent) and appearing in medium category would be two third of its total members i.e. 61.43 per cent.

\section{Conceptual Framework}

Women empowerment through SHGs would be measured based on the contributions of three types of empowerment namely, personal empowerment, social empowerment and economic empowerment.

The Personal empowerment (Pe) is measured based on two constructs namely self development with four items and decision making with eight items. Hence, personal empowerment would be calculated using twelve indicators.

The Social empowerment (Se) is measured based on three constructs namely, social status with four items, decision making with eight items and political \& legal awareness with five items. Hence, social empowerment would be calculated using seventeen indicators.

The Economic empowerment (Ee) is measured based on two constructs namely economic status with four items and decision making with eight items. Similarly, economic empowerment would be calculated using twelve indicators.

\section{Author's Model on Women Empowerment through SHGs}

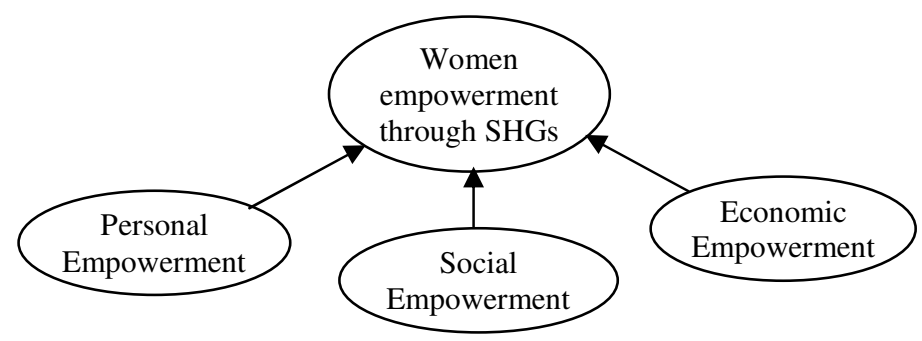




\section{Objectives of the Study}

- To understand the after math effect of women joining SHGs.

- To explore the factors that paves path to women empowerment with the influence of SHGs women.

- To furnish the research model, based on which the data could be collected from the large sample.

\subsection{Rationale of the Study}

\section{Research Methodology}

This study is the pilot study of the major research pertaining to nearly 2500 SHGs women. Hence, developed scale would be adopted for the main research. With which, the proposed research model would be checked for its feasibility in the current scenario of SHGs activities of women all over Tamil Nadu.

\subsection{Research}

Exploratory research is conducted for an issue that has not been studied more clearly and also intends to establish priorities, develop operational definitions and improve the final research design.

\subsection{Data Source}

The study employed both the primary data and secondary data. The primary data was collected from the respondents using self administered questionnaire. The secondary data was from various research papers and articles, accessed from online databases like EBSCO Host, Emerald Insight, INFLIBNET, MENDELEY, JSTOR and National Digital Library (NDL).

\subsection{Sampling Frame}

By adopting stratified random sampling, data were collected from 95 SHGs Women using self administered questionnaire. All of them were the Group heads. So, each one from 95 SHGs participated in this study.

\subsection{Sample Area}

The respondents belong to Krishnagiri District of the State Tamil Nadu.

\subsection{Questionnaire Design}

The questionnaire was designed and reviewed by the research experts to ensure the feasibility of receiving the response that would satisfy the needs of the study. Finally the questionnaire was translated to the vernacular language (Tamil) using back translation technique.

\subsection{Pre Testing of Questionnaire}

The questionnaire designed and translated was distributed to 15 SHGs women to make sure that they are able to answer the questions. As a result of the pre testing few changes were made with reference to the language style rather than the content of the questionnaire. These changes were incorporated for easier understanding to the respondents. 
5.8 Statistical Tools

- SPSS was employed to enter the collected data and to proceed with Exploratory Factor Analysis (EFA).

- AMOS Graphics was employed to find the fit indices of each constructs.

- Smart PLS and ADANCO software to analyse few tests namely, composite reliability, discriminant validity and convergent validity.

\section{Scale Reliability and Validity}

\section{Empirical Analysis and Results}

\subsection{Face Validity}

Face validity is a component of content validity while others believe it is not. Face validity is established when an individual (and or researcher) who is a specialist on the research subject reviewing the questionnaire (instrument) concludes that it measures the characteristic or trait of interest. Face validity involves the expert glancing at the items in the questionnaire and agree that the test is a valid measure of the concept which is being measured just on the face of it. Face validity is often said to be very informal, soft and many researchers do not consider this as an active measure of validity. However, it is the most widely used form of validity in developing Countries.

Similarly, the questionnaire of this research were glanced by ten academicians who are the researchers as well. Then, the questionnaire was distributed to the respondents for collecting the data.

\subsection{Model Exploration and Refinement}

The study has used exploratory factor analysis (EFA) with a varimax rotation and was conducted on the 55 variables to find the major factors that contribute towards the empowerment of women. The Kaiser - Meyer - Olkin (KMO) measure is an indicator of how well suited the sample data is for factor analysis. It is the ratio of the sum of the squared partial correlations for all variables. The denominator of this ratio increases with the variation that is unique to pairs of variables (partial correlations), making the value of KMO less than 1. Small values of KMO indicate that factor analysis may not be appropriate for the data. Kaiser (1974) suggests that values of 0.9 or values greater than 0.5 is acceptable.

Table 1 KMO Analysis

\begin{tabular}{|l|l|c|}
\hline Kaiser - Meyer - Olkin Measure of Sampling Adequacy & $\mathbf{0 . 8 1 5}$ \\
\hline \multirow{3}{*}{ Barlett's Test of Sphericity } & Approx. Chi-Square & 3890.137 \\
\cline { 2 - 3 } & df & 820 \\
\cline { 2 - 3 } & sig. & 0.000 \\
\hline
\end{tabular}

Inference: From the above Table, value of the Barlett's test of sphericity is found to be 0.000 which is at significant level and also the $\mathrm{KMO}$ value is 0.815 which is greater than 0.5 , hence the factor analysis proceeded for the data is appropriate.

There were three first order factors using principal component method explaining 75 per cent total variations. The principal component matrix was rotated and a factor loading above 0.4 was used for naming the factors. 


\subsection{Internal Homogeneity}

Usually researchers employ internal consistency measure is the Cronbach's coefficient alpha. Cronbach alpha represents the mean of all split half coefficients resulting from different splitting of a test (Cronbach, 1951). Besides this, Hair et. al. (2010) recommend that generally lower limit for Cronbach's alpha as 0.70 is accepted, although it may decrease to 0.60 in exploratory research.

Table 2 Cronbach's Alpha, Means and Standard Deviations for all the Seven Scales

\begin{tabular}{|l|c|c|c|c|}
\hline \multicolumn{1}{|c|}{ Scales } & $\begin{array}{c}\text { Cronbach's } \\
\text { Alpha }\end{array}$ & $\begin{array}{c}\text { Composite } \\
\text { Reliability }\end{array}$ & Mean & $\begin{array}{c}\text { Std. } \\
\text { Deviation }\end{array}$ \\
\hline Pe-Self Development & 0.8905 & 0.895 & 1.723 & 0.632 \\
\hline Pe-Decision Making & 0.8637 & 0.874 & 1.877 & 0.910 \\
\hline Se-Social Status & 0.7612 & 0.964 & 1.976 & 0.901 \\
\hline Se-Decision Making & 0.8979 & 0.863 & 1.975 & 0.966 \\
\hline $\begin{array}{l}\text { Se-Political and legal } \\
\text { awareness }\end{array}$ & 0.7594 & 0.898 & 1.974 & 0.958 \\
\hline Ee-Economic Status & 0.7700 & 0.774 & 1.923 & 0.923 \\
\hline Ee-Decision Making & 0.8388 & 0.701 & 2.014 & 1.064 \\
\hline
\end{tabular}

Inference: The above Table 2 indicates that alpha values are greater than 0.7 for all the seven scales. Hence, the measurement model is reliable as per Nunally (1978). The values of composite reliability is also greater than 0.7 depicting the model as a reliable as per Fornell and Larcker (1981).

\subsection{Construct Validity}

This is the step adopted by the researchers that measures the extent to which a set of measured items actually reflects the theoretical latent construct those items are designed to measure (Hair et. al, 2010). Construct validity is investigated through discriminant validity, convergent validity and Inter construct correlations.

\section{Discriminant Validity}

Discriminant validity is the extent to which latent variable A discriminates from other latent variables. Discriminant validity means that a latent variable is able to account for more variance in the observed variables associated with it. (Fornell \& Larcker, 1981).

To confirm the discriminant validity of the measure, AVE of each construct used in the model must be greater than the squared correlation of that construct to satisfy the discriminant validity tests.

Inference : From the above Table it is found that, AVE of the construct is greater than the squared correlation of the respective construct in case of four constructs namely Pe - Self development, Se-Political \& legal awareness, Ee - Economic status and Ee - Decision making. But in case of Pe - Decision making, Se-Social Status and Se-Decision Making, the AVE of the construct is not greater than the squared correlation of the respective constructs. 
Table 3 Discriminant Validity

\begin{tabular}{|l|c|c|c|c|c|c|c|}
\hline \multicolumn{1}{|c|}{ Scales } & $\begin{array}{c}\text { Pe- Self } \\
\text { Development }\end{array}$ & $\begin{array}{c}\text { Pe- } \\
\text { Decision } \\
\text { Making }\end{array}$ & $\begin{array}{c}\text { Se- } \\
\text { Social } \\
\text { Status }\end{array}$ & $\begin{array}{c}\text { Se- } \\
\text { Decision } \\
\text { Making }\end{array}$ & $\begin{array}{c}\text { Se- } \\
\text { Political \& } \\
\text { legal } \\
\text { awareness }\end{array}$ & $\begin{array}{c}\text { Ee- } \\
\text { Economic } \\
\text { Status }\end{array}$ & $\begin{array}{c}\text { Ee- } \\
\text { Decision } \\
\text { Making }\end{array}$ \\
\hline $\begin{array}{l}\text { Pe-Self } \\
\text { Development }\end{array}$ & 0.7600 & & & & & & \\
\hline $\begin{array}{l}\text { Pe-Decision } \\
\text { Making }\end{array}$ & 0.6571 & 0.5127 & & & & & \\
\hline $\begin{array}{l}\text { Se-Social } \\
\text { Status }\end{array}$ & 0.4930 & 0.6160 & 0.5859 & & & & \\
\hline $\begin{array}{l}\text { Se-Decision } \\
\text { Making }\end{array}$ & 0.6806 & 0.6621 & 0.6684 & 0.5852 & & & \\
\hline $\begin{array}{l}\text { Se-Political } \\
\text { \& legal } \\
\text { awareness }\end{array}$ & 0.3448 & 0.3192 & 0.4262 & 0.4767 & 0.5229 & & \\
\hline $\begin{array}{l}\text { Ee-Economic } \\
\text { Status }\end{array}$ & 0.4694 & 0.4951 & 0.5350 & 0.5692 & 0.4476 & 0.5161 & \\
\hline $\begin{array}{l}\text { Ee-Decision } \\
\text { Making }\end{array}$ & 0.3865 & 0.2931 & 0.3817 & 0.4702 & 0.5345 & 0.4683 & 0.4857 \\
\hline
\end{tabular}

\section{Convergent Validity}

Convergent validity involves the degree to which individual items reflecting a construct converge in comparison to items measuring different constructs (Urbach et. al, 2010). A common criterion applied to test the convergent validity is based on Average Variance Extracted (AVE) proposed by Fornell and Larcker (1981). According to which, AVE values should be greater than 0.5 indicating that the construct is captured to be explained more than half of the variance of its indicators. In particular, any construct with AVE value below 0.5 point outs that it consists of measurement residual.

Table 4 Convergent Validity

\begin{tabular}{|l|c|}
\hline \multicolumn{1}{|c|}{ Constructs } & Average Variance Extracted (AVE) \\
\hline Pe-Self Development & 0.7600 \\
\hline Pe-Decision Making & 0.5127 \\
\hline Se-Social Status & 0.5859 \\
\hline Se-Decision Making & 0.5852 \\
\hline Se-Political and legal awareness & 0.5229 \\
\hline Ee-Economic Status & 0.5161 \\
\hline Ee-Decision Making & 0.5746 \\
\hline
\end{tabular}

Inference: From the above Table it is found that, the AVE values of all the scales exceeded the recommended threshold level of 0.50 (Bagozzi \& Yi, 1988). Hence the scales are confined to be explained more than half of the variance of its indicators and thus demonstrate convergent validity.

\section{Goodness of Fit Indices}

Before performing Structural Equation Modelling, researchers generally rely on number of Goodness of Fit (GFI) indices to validate the fit between the theoretical 
model and the data (Carter \& Jennings, 2002). Here, authors have used Bentler's (1989) Comparative Fit Index (CFI) and Bentler and Bonett's (1980) Normed Fit Index (NFI) for approximation. Values of 0.9 or above for the CFI and NFI suggest an appropriate fit between the model and the data (Baumgartner \& Homburg, 1996; Brown \& Cudeck, 1993).

In addition, the authors also examined the Root Mean square Residual (RMR) whose value below 0.05 is regarded as evidence that the model predicts the observed covariances among items very well.

Table 5 Goodness of Fit Indices for all the Scales

\begin{tabular}{|l|c|c|c|c|}
\hline \multirow{2}{*}{\multicolumn{1}{c|}{ Scales }} & \multicolumn{4}{c|}{ Index of Fit } \\
\cline { 2 - 5 } & GFI & CFI & NFI & RMR \\
\hline $\mathrm{Pe}$ - Self Development & 0.995 & 0.999 & 0.976 & 0.008 \\
\hline $\mathrm{Pe}$ - Decision Making & 0.923 & 0.970 & 0.928 & 0.042 \\
\hline $\mathrm{Se}$ - Social Status & 0.978 & 0.971 & 0.964 & 0.030 \\
\hline $\mathrm{Se}$ - Decision Making & 0.987 & 0.944 & 0.913 & 0.054 \\
\hline $\mathrm{Se}$ - Political \& Legal Awareness & 0.979 & 0.986 & 0.969 & 0.036 \\
\hline Ee - Economic Status & 0.970 & 0.931 & 0.907 & 0.043 \\
\hline Ee - Decision Making & 0.911 & 0.928 & 0.963 & 0.054 \\
\hline
\end{tabular}

Inference: From the above Table it is found that, values of GFI, CFI and NFI are greater than 0.9 for all the scales. RMR values are found to be less than 0.05 for all the scales except two scales namely, Se - Decision Making (0.054) and Ee Decision Making (0.054).

Almost all the values are satisfying the conditions except two that too for the case of RMR only. Therefore, the fit indices of the scales developed can be accepted.

\section{Scale Development}

The scales identified were tested for their internal consistency using Cronbach's alpha and composite reliability. Also the scales developed were validated using face validity, convergent validity, discriminant validity. In addition to that, goodness of fit indices were also found for each scales. To certain extent, the scales developed are in positive terms.

\section{Implications}

The proposed research model would be applied to the large sample size and based on the results, the strategies for the betterment of SHGs women can be formulated in all other districts of Tamil Nadu.

\section{Conclusion}

This study is an attempt to examine after math of women entering Self Help Groups. The intervening effect of SHGs towards empowerment of women would be studied in detail in future with large sample size. This analysis of this study grants a positive flash that the role of Self Help Groups contributes to the women empowerment. 
Hence forth, the scale developed can be accepted for further proceedings of main research as well.

\section{Acknowledgement}

I thank Mr. Kulandei Francis, Founder of Integrated Village Development Project (IVDP), NGO, Krishnagiri, Tamil Nadu, India, for his valuable support to collect the data from the SHGs women of Krishnagiri District. I would like to thank Mr. Cyril Fernandez (Rtd), General Manager of Material Management, BHEL, Ranipet, Vellore, Tamil Nadu, India, for his valuable suggestions and guidance for the research work to proceed in the right path.

\section{References}

1. Bora, B. (2017). Self Help Groups and Women Empowerment $\square$ : A study of selected Self Help Groups in Dolongghat Development Block of Nagaon District of Assam, 6959(86), 86-94.

2. Kondal, K. (2014). Women Empowerment through Self Help Groups in Andhra Pradesh, India, 3(1), 13-16.

3. Kote, A. K. B., \& Honnakeri, P. M. (2012). Impacts of Microfinance on Poverty Alleviation and the Empowerment of Women with Special Reference to Rural Women Empowerment and Entrepreneurship https://doi.org/http://ijrcm.org.in/commerce/index.php

4. Moon, U. (2011). Role of Self Help Group - Bank Linkage Model in Women Empowerment. Asia Pacific Journal of Research in Business Management.

5. Naik, M., \& Rodrigues, A. (2017). Women Empowerment through Self Help Groups $\square$ : Realities and Challenges, 22(6), 1-9. https://doi.org/10.9790/08372206120109

6. Sahoo, A. (2013). Self Help Group \& Woman Empowerment $\square$ : A study on some selected SHGs. International Journal of Business and Management Invention, 2(9), 54-61.

7. Shambharkar, Y. B., Jadhav, U. V, \& Mankar, D. M. (2012). Impact of Self Help Groups on Empowerment of Women Member, II (Volume II), 188-192.

8. Sundaram, A. (2012). Impact of Self-help Group in Socio-economic development of India. Journal of Humanities and Social Science, 5(1), 20-27.

9. Thangamani, S., \& Muthuselvi, S. (2013). A Study on Women Empowerment through Self-Help Groups with Special Reference to Mettupalayam Taluk in Coimbatore District. IOSR Journal of Business and Management.

10. Vetrivel, S. C., \& Chandrakumaramangalam, S. (2010). Role of Micro Finance on Women Empowerment through Self Help Groups in Tamilnadu. Advnaces in Management.

11. Arif, Z. U. (2014). Women Empowerment and Poverty Reduction through Participation of Women in Micro- finance with Reference to Bangladesh. ANVESHAK-International Journal of Management, 3(5), 41.https://doi.org/10.15410/aijm/2014/v3i5/53727

12. Gozukara, I., \& Simsek, O. F. (2016). Role of leadership in employees' work engagement: Organizational identification and job autonomy. International Journal of Business and Management, 11(1), 72. https://doi.org/10.5539/ijbm.v11n1p72 
13. Harikrishnan, V., \& Karuppasamy, R. (2017). The role of micro finance towards empowerment of women self help groups. International Journal of Applied Business and Economic Research, 15(16), 423-434.

14. Mathur, P., \& Agarwal, P. (2017). Self-help groups: a seed for intrinsic empowerment of Indian rural women.Equality, Diversity and Inclusion: An International Journal, 36(2), 182-196. https://doi.org/10.1108/EDI-052016-0039

15. Moyle, T. L., Dollard, M., \& Biswas, S. N. (2006). Personal and Economic Empowerment in Rural Indian Women: A Self-help Group Approach. International Journal of Rural Management. https://doi.org/10.1177/097300520600200207

16. Suja, S. (2012). Women Empowerment through Self-Help Group- an Evaluative Study. Global Management Review, 6(3), 68-82. Retrieved from http://search.ebscohost.com/login.aspx?direct=true \&db=bth\&AN=79934815\&si te=ehost-live

17. Anuradha, P. S. (2012). An Empirical Study on Socio-economic Empowerment of Women through Self Help Groups. International Journal of Research in Commerce, Economics and Management, 2(1), 84-86. https://doi.org/10.9790/487X-1907063545

18. Das, S. K. (2012). Best Practices of Self Help Groups and Women Empowerment: A Case of Barak Valley of Assam. Far East Journal of Psychology and Business.

19. Kotishwar, A., \& Khan, M. A. A. (2010). Women Empowerment through Self Help Groups--A Case Study of Nizamabad District of Andhra Pradesh. International Journal of Research in Commerce and Management, 1(1), 48-71. Retrieved

from https://ezproxy.bibl.ulaval.ca/login?url=http://search.proquest.com/docview/901 300035?accountid=12008\%5Cnhttp://sfx.bibl.ulaval.ca:9003/sfx_local??url_ver =Z39.882004\&rft_val_fmt=info:ofi/fmt:kev:mtx:journal\&genre=article\&sid=Pr oQ:ProQ\%3Aeconlitshell\&atit

20. Suprabha, K. R. (2014). Empowerment of Self Help Groups (SHGs) towards Microenterprise Development. Procedia Economics and Finance, 11(14), 410422.https://doi.org/10.1016/S2212-5671(14)00208-1

21. Tesoriero, F. (2006). Strengthening communities through women's self help groups in South India. Community Development Journal. Https://doi.org/10.1093/cdj/bsi066

22. Vijayanthi, K. N. (2002). Women's Empowerment through Self-help Groups: A Participatory Approach. Indian Journal of Gender Studies. https://doi.org/10.1177/097152150200900209

23. Robert A. Peterson, A meta analysis of Cronbach's coefficient alpha, Journal of Consumer Research Vol. 21, No. 2 (Sep., 1994), pp. 381-391

24. Browne, M. W., \& Cudeck, R. (1993). Alternative ways of assessing model fit. In K. A. Bollen and J. S. Long (Eds.), testing structural equation models (pp. 136-162). Newbury Park, CA: Sage.

25. Bagozzi, R.P., Yi, Y., and Phillips, L.W. (1991), "Assessing Construct Validity in Organizational Research," Adminstrative Science Quarterly, 36 (3), 421-58.

26. Barrett, P. (2007), "Structural Equation Modeling: Adjudging Model Fit," Personality and Individual Differences, 42 (5), 815-24. 
27. Bentler, P.M. (1990), "Comparative Fit Indexes in Structural Models," Psychological Bulletin, 107 (2), 238-46.

28. Bentler, P.M. and Bonnet, D.C. (1980), "Significance Tests and Goodness of Fit in the Analysis of Covariance Structures," Psychological Bulletin, 88 (3), 588606.

29. Fornell, C. G., \& Larcker, D. F. (1981). Evaluating structural equation models with unobservable variables and measurement error. Journal of Marketing Research, 18(1), 39-50.

30. Hair, J. F., Black, W. C., Babin, B. J., \& Anderson, R. E. (2010). Multivariate data analysis (7th ed.). Englewood Cliffs: Prentice Hall.

31. Jörg Henseler \& Christian M. Ringle \& Marko Sarstedt, A new criterion for assessing discriminant validity in variance-based structural equation modelling, J. of the Acad. Mark. Sci. (2015) 43:115-135DOI 10.1007/s11747-014-0403-8

32. Henseler, J., \& Sarstedt, M. (2013). Goodness-of-fit indices for partial least squares path modeling. Computational Statistics, 28(2), 565-580.

33. Henseler, J., Ringle, C. M., \& Sinkovics, R. R. (2009). The use of partial least squares path modeling in international marketing. Advances in International Marketing, 20, 277-320.

34. Hair, J. F., Hult, G. T. M., \& Calantone, R. J. (2014). Common beliefs and reality about partial least squares: comments on Rönkkö \& Evermann (2013). Organizational Research Methods, 17(2), 182-209

\section{About Our Authors}

Beulah Suresh heads the Department of Business Administration of Auxilium College (Autonomous), Vellore. She has 17 years of experience in teaching and Research. Her area of specialization is marketing. She worked on women consumer behavior towards offers and discounts as part of her research in obtaining her Doctoral Degree. She also serves as the Guest Faculty, handling classes for Prison officers in Academy of Prisons and Correctional Administration (APCA), Vellore. She also conducts workshop on life style management for Prison officers all over the Nation collaborating with APCA. She is also the Research Supervisor for Ph. D and M. Phil Scholars.

Arivuselvee V. J. is a Ph. D Research Scholar of Auxilium College working under the Guidance of Dr. Beulah Suresh. Her area of specialization is Human Resource, which motivated her to choose the topic "The role of Self Help Groups in Empowering women at Krishnagiri District" to receive her Doctoral Degree. She is interested in the field of statistics. She pursued her Project work in Christian Medical College Hospital, Vellore as part of her Post Graduation curriculum. She worked on research papers on Motivational factors and work engagement of the employees at Greaves Cotton Limited, Ranipet, Vellore in obtaining her M. Phil Degree. 